\title{
TINGKAT PENGETAHUAN REMAJA TENTANG HIV / AIDS DI KOTA PEKALONGAN
}

\author{
Dwi Edi Wibowo, Saeful Marom
}

Universitas Pekalongan

dwiediwibowo73@yahoo.co.id, Maromsaiful@yahoo.com

\begin{abstract}
ABSTRAK
Masa remaja adalah suatu tahap peralihan antara masa anak-anak dengan masa dewasa. Lazimnya masa remaja dimulai saat anak secara seksual menjadi matang dan berakhir saat mencapai usia matang tersebut. Masa remaja ini terjadi beberapa perubahan atau perkembangan yang terjadi antara lain perkembangan fisik, perkembangan emosional dan perkembangan seksual. Dengan adanya perkembangan seksual,keingintahuan remaja tentang seks menjadi lebih besar dan dorongan seks pun meningkat (Hurlock, 1999). Maraknya seks bebas di Kota Semarang, harus diwaspadai oleh para remaja yang tinggal di wilayah tersebut. Pasalnya, bila tidak berhati-hati mereka bisa tertular salah satu virus mematikan HIV/AIDS.Berdasarkan data dari Perkumpulan Keluarga Berencana Indonesia (PKBI), saat ini ada sebanyak 4.472 orang yang telah terinfeksi virus HIV/AIDS, permasalahan dalam penelitian ini adalah "Bagaimana Tingkat Pengetahuan Remaja Tentang HIV / AIDS di Kota Pekalongan?”. Tujuan penelitian adalah adalah mengetahui tingkat pemahaman remaja tentang pengetahuan HIV/AIDS, mengetahui sumber informasi remaja tentang HIV/AIDS, mengetahui tingkat pemahaman remaja tentang sikap terhadap HIV/AIDS ,mengetahui tingkat pengetahuan remaja tentang perilaku yang beresiko tertular HIV/AIDS . Metode penelitian yang digunakan adalah metode survei, yaitu pengumpulan data meliputi data primer dan data sekunder. Dalam pengambilan data primer ini, peneliti melakukan wawancara terstruktur dengan menggunakan questionaire, dengan pemilihan sampel menggunakan metode random sampling. Pengumpulan data sekunder dilakukan dengan menggunakan data - data yang telah ada sebelumnya.

Berdasarkan hasil wawancara dengan beberapa guru BK di SMA/MA/SMK dikota Pekalongan menyatakan bahwa siswa banyak menampakkan kebebasan mandiri pada kelas XI (usia antara 16-18 tahun) disebabkan pada jenajang kelas XI mereka merasa bebas karena mereka mempunyai yunior yaitu kelas X dan akan kembali stabil lagi ketika kelas XII karena siswa sudah konsentrasi untuk menghadapi Ujian Akhir Nasional. Berdasarkan masukan dari Guru BK di SMA/MA/SMK maka peneliti mengambil sampel kelas XI di SMA/SMK/MA di Kota Pekalongan. Selanjutnya untuk dikarenakan hasil wawancara dengan Guru BK di Sekolah dengan beberapa pertanyaan mengenai masalah kenakalan siswa jawaban semuanya hampir sama bahkan bisa dikatakan sama sehingga jadi tim peneliti menyimpulkan bahwa keadaan siswa SMA/SMK/MA bisa dikatakan sama sehingga untuk menjaga persebaran responden dan dapat mewakili dari tiap bagian kota pekalongan peneliti mendata sekolah di tiap bagian Kota Pekalongan dan memilih secara acak sekolah tersebut sehingga pada akhirnya diperoleh sampelnya adalah :MAN 2 Kota Pekalongan mewakili Kota Pekalongan Bagian Barat,SMK Gatra Praja mewakili Kota Pekalongan Bagian Utara,SMA Hasyim Asy'ari mewakili Kota Pekalongan Bagian Timur,SMA N 4 Kota pekalongan mewakili Kota Pekalongan Bagian Selatan. Kesimpulan Tingkat pengetahuan remaja tentang HIV/ AIDS di Kota Pekalongan adalah cukup sebesar ( 56,73\% ). Saran terhadap stakeholder terkait dengan hasil penelitian, Stakeholder terkait dapat meningkatkan sosialisasi terhadap remaja tentang pengetahuan HIV / AIDS agar tingkat pengetahuan remaja menjadi naik, adanya koordinasi antar instansi dalam memberikan sosialisasi kepada masyarakat, memberikan sosialisasi kepada seluruh lapisan masyarakat agar info yang diberikan tersebar luas ,menambah jenis media info yang digunakan untuk sosialisasi HIV/AIDS.
\end{abstract}

Kata Kunci : Pengetahuan, Remaja , HIV / AIDS 


\section{PENDAHULUAN}

Masa remaja adalah suatu tahap peralihan antara masa anak-anak dengan masa dewasa. Lazimnya masa remaja dimulai saat anak secara seksual menjadi matang dan berakhir saat mencapai usia matang tersebut. Masa remaja ini terjadi beberapa perubahan atau perkembangan yang terjadi antara lain perkembangan fisik, perkembangan emosional dan perkembangan seksual. Dengan adanya perkembangan seksual, keingintahuan remaja tentang seks menjadi lebih besar dan dorongan seks pun meningkat (Hurlock, 1999). Maraknya seks bebas di Kota Semarang, harus diwaspadai oleh para remaja yang tinggal di wilayah tersebut. Pasalnya, bila tidak berhati-hati mereka bisa tertular salah satu virus mematikan HIV/AIDS. Berdasarkan data dari Perkumpulan Keluarga Berencana Indonesia (PKBI), saat ini ada sebanyak 4.472 orang yang telah terinfeksi virus HIV/AIDS. Dari jumlah sebanyak itu, 20 persen atau 400 orang di antaranya merupakan remaja yang tinggal di Jawa Tengah 70 persen di antaranya ditemukan di Kota Semarang. Untuk jumlah kasusnya sendiri mulai Oktober-Desember 2013, kami telah menemukan 437 kasus, kata Staf Program HIV/AIDS PKBI, Slamet Riyadi, di Kota Semarang, Jawa Tengah, Senin (1/9). Slamet mengatakan, dengan estimasi itu maka setiap bulannya minimal terdapat 14-15 remaja di Kota Semarang positif terinfeksi virus menular tersebut. Menurut Slamet, hal itu mayoritas dipengaruhi perilaku seks bebas di kalangan anak muda. Sedangkan, 20 persen di antaranya karena penggunaan obat-obatan terlarang "Anak-anak muda di sini yang kena HIV/AIDS berusia rata-rata 15-20 tahun", urainya.

Slamet mengaku sangat mengkhawatirkan perilaku seks bebas ini. Sebab, saat ini remaja yang gemar seks bebas semakin nekat bahkan ada beberapa remaja memilih membuka bisnis pelacuran di dunia maya. "Itu belum lagi ditambah pengaruh kekerasan seksual dan homoseksual", terang Slamet. Dia menyebut, bahwa kasus penyebaran HIV/AIDS secara keseluruhan di Jateng cenderung meningkat. Bila pada 2012 hanya ada 607 kasus maka pada 2013 mencapai lebih dari 1000 kasus. "Ini artinya, lonjakan kasusnya cukup signifikan. Meski demikian, kami kini terus menekan penyebaran HIV/AIDS dengan memberikan obat pencegah virus HIV", ucapnya.

Kejadian di atas tidak hanya terjadi di kota-kota besar saja, bahkan sudah merambah ke daerah pinggiran kota. Seperti di Pekalongan, Jawa Tengah telah ditemuka adegan mesum selayaknya pasangan suami istri yang dilakukan oleh pelajar SMA Swasta (Resapugar, 2010). Pekalongan khususnya Desa Wonopringgo kini jumlah warung internet (warnet) bertambah. Tahun 2008 terdapat 3 warung internet dan meningkat pada tahun 2010 menjadi 10 warung internet. Warung internet dengan mudah dapat dimasuki oleh berbagai kalangan usia terutama kalangan remaja. Hal ini harus diwaspadai karena tanpa adanya pengawasan yang baik dari pemilik warnet maka dengan mudahnya remaja-remaja dapat mengakses pornografi. Selain pengaruh adanya warung internet, pergaulan remaja, dan rasa ingin tahu pun juga dapat memicu timbulnya hubungan seks pranikah pada kalangan remaja.

Masalah HIV/AIDS merupakan masalah besar yang mengancam banyak negara di dunia, tak terkecuali di Indonesia. Laporan terakhir Direktorat Jenderal Pengendalian Penyakit dan Penyehatan Lingkungan (P2PL) Kementrian Kesehatan Republik Indonesia Tahun 2010 jumlah kumulatif dari 1 Januari 1987 sampai dengan 30 Juni 2010 kasus AIDS di Indonesia adalah 
21.770 orang dengan jumlah kematian 4.128 orang. Provinsi Jawa Tengah merupakan salah satu provinsi di Indonesia dengan jumlah kumulatif AIDS yang tinggi yaitu 819 orang dengan jumlah kematian 265 orang .

Jumlah pengidap HIV/AIDS di Kota Pekalongan mengalami pelonjakan. Sepanjang Januari hingga September 2012, jumlah pengidap HIV/AIDS sebanyak 12 orang. Jumlah itu ada kenaikan dibanding dalam waktu yang sama dari Januari sampai September 2011 tercatat ada sembilan orang. Demikian disampaikan Kabid Pengawasan Pengendalian dan Penyehatan Lingkungan (P2PL) Dinas Kesehatan Kota Pekalongan. Tuti Widyati pada sosialisasi Pencegahan HIV/AIDS di Ruang Jatayu Setda. Tema kegiatan hari itu "Lindungi Perempuan dan Anak dari HIV/AIDS," Tuti memaparkan, dari Januari hingga September tahun ini, ada lima orang terdeteksi mengidap HIV dan tujuh orang mengidap AIDS. Sementara pada tahun lalu, pengidap HIV hanya satu orang, sedangkan yang terjangkit AIDS delapan orang. Menurut dia, meningkatnya pengidap HIV/AIDS tersebut disebabkan Komisi pengendalian AIDS Daerah (KPAD) Kota Pekalongan belum operasional secara optimal. Selain itu, klinik Voluntary Counceling and Testing (VCT) juga belum diakses secara maksimal. "Belum banyak masyarakat yang memanfaatkan klinik VCT", terangnya. Selain itu, terbatasnya obat ARV juga dinilai menjadi salah satu faktor yang memberikan kontribusi terhadap meningkatnya jumlah penderita HIV/AIDS di Kota Pekalongan.

Badan Narkotika Kota (BNK) Pekalongan menyatakan, kota itu menempati urutan 10 besar daerah peredaran narkotika dan obat-obatan berbahaya (narkoba) di Jawa Tengah. Menurutnya, tingginya peredaran narkoba di Kota Batik itu berdampak meningkatnya kasus HIV/AIDS di daerah Pekalongan khususnya bagi pengguna jarum suntik. Berdasarkan data 2011, kata Alf, jumlah penderita HIV/AIDS di Kota Pekalongan sebanyak 38 orang atau meningkat di banding tahun sebelumnya yang mencapai hanya belasan orang. Mereka yang terjangkit penyakit HIV tersebut sebagian besar karena pemakaian jarum suntik secara bergantian saat mengkonsumsi narkoba. Tujuan dari penelitian ini adalah mengetahui tingkat pengetahuan remaja tentang HIV/AIDS di Kota Pekalongan dengan sasarannya sebagai berikut mengetahui tingkat pemahaman remaja tentang pengetahuan HIV/AIDS di Kota Pekalongan, mengetahui sumber Informasi remaja tentang HIV/AIDS, mengetahui tingkat pemahaman remaja tentang sikap terhadap HIV/AIDS di Kota Pekalongan, mengetahui tingkat pengetahuan remaja tentang perilaku yang beresiko tertular HIV/AIDS di Kota Pekalongan. Penelitian sejenis sudah dilakukan dengan judul Tingkat Pengetahuan HIV/AIDS dan Sikap Remaja Terhadap Perilaku Seksual Pranikah di SMA X Jakarta Timur. Tujuan dari penelitian ini adalah untuk mengidentifikasi hubungan antara tingkat pengetahuan HIV/AIDS dan sikap remaja terhadap perilaku seksual pranikah. Metode dalam penelitian adalah deskriptif korelatif, pengambilan data dilakukan dengan menggunakankuesioner dan teknik purposive sampling. Hasil penelitian mayoritas siswa memiliki tingkat peengetahuan HIV/AIDS yang baik dengan sikap tidak mendukung terhadap perilaku sex.

\section{METODE PENELITIAN}

Metode penelitian yang digunakan adalah metode survei, yaitu pengumpulan data meliputi data primer dan data sekunder. Dalam pengambilan data primer ini, peneliti melakukan wawancara terstruktur dengan menggunakan 
questionaire, dengan pemilihan sampel menggunakan metode random sampling. Pengumpulan data sekunder dilakukan dengan menggunakan data - data yang telah ada sebelumnya.

Langkah pertama penelitian diawali dengan pengumpulan data sekunder berupa pengumpulan data banyaknya sekolah di Kota Pekalongan. Kota Pekalongan terbagi menjadi empat bagian yaitu pekalongan utara, pekalongan selatan, pekalongan barat, dan pekalongan timur. Pada penelitin ini obyek yang akan diteliti adalah Remaja di Kota pekalongan. Menurut Depkes RI dan BKKBN batasan remaja adalah antara 10-19 Tahun dan Belum kawin. Menurut (Widiastuti, 2009) salah satu sifat atau ciri perkembangannya masa remaja akhir yaitu menampakkan kebebasan mandiri pada usia 16-19 Tahun. Berdasarkan hasil wawancara dengan beberapa guru BK di SMA/MA/SMK dikota Pekalongan menyatakan bahwa siswa banyak menampakkan kebebasan mandiri pada kelas XI (usia antara 16-18 tahun) disebabkan pada jenajang kelas XI mereka merasa bebas karena mereka mempunyai yunior yaitu kelas $\mathrm{X}$ dan akan kembali stabil lagi ketika kelas XII karena siswa sudah konsentrasi untuk menghadapi Ujian Akhir Nasional. Berdasarkan masukan dari Guru BK di SMA/MA/SMK maka peneliti mengambil sampel kelas XI di SMA/SMK/MA di Kota Pekalongan. Selanjutnya untuk dikarenakan hasil wawancara dengan Guru BK di Sekolah dengan beberapa pertanyaan mengenai masalah kenakalan siswa jawaban semuanya hampir sama bahkan bisa dikatakan sama sehingga jadi tim peneliti menyimpulkan bahwa keadaan siswa SMA/SMK/MA bisa dikatakan sama sehingga untuk menjaga persebaran responden dan dapat mewakili dari tiap bagian kota pekalongan peneliti mendata sekolah di tiap bagian Kota Pekalongan dan memilih secara acak sekolah tersebut sehingga pada akhirnya diperoleh sampelnya adalah :

1. MAN 2 Kota Pekalongan mewakili Kota Pekalongan Bagian Barat

2. SMK Gatra Praja mewakili Kota Pekalongan Bagian Utara

3. SMA Hasyim Asy'ari mewakili Kota Pekalongan Bagian Timur

4. SMA N 4 Kota pekalongan mewakili Kota Pekalongan Bagian Selatan

Data penelitian ini adalah data primer dan data sekunder. Instrumen penelitian dalam penelitian ini adalah kuesioner, wawancara, kamera dan alat tulis untuk dokumentasi. Pengumpulan data primer dilakukan dengan memberikan kuesioner kepada siswa kelas XI di SMA Hasyim As'yari, SMA 4, SMK Gatra Praja, MAN 2 yang berisi pengetahuan tentang HIV/AIDS, sumber informasi tentang HIV/AIDS, sikap terhadap HIV/AIDS, perilaku yang beresiko tertular HIV/AIDS. Wawancara dilakukan dengan guru BK (bimbingan konseling) di tiap SMA yang dijadikan sample :

1. Analisa pengetahuan tentang HIV/AIDS

Setelah melakukan wawancara dengan Guru BK di 4 sekolah tersebut pengetahuan tentang HIV/AIDS masih kurang karena mereka kurang mendapatkan pencerahan dari instansi terkait seperti penyuluhan

2. Analisa tentang sumber informasi tentang HIV/AIDS

Setelah melakukan wawancara dengan guru BK sebagian besar guru BK juga belum tahu secara maksimal apa itu penyakit AIDS, ditambah lagi siswanya yang tidak tahu sumber informasi yang benar tentang penyakit HIV/AIDS

\section{Analisa sikap terhadap HIV/AIDS}

Setelah melakukan wawancara dengan Guru BK sebagian besar siswa 
tidak paham tentang penyakit HIV/AIDS, dan masih jarang adanya sosialisasi tentang penyakit HIV/AIDS

4. Analisa perilaku yang beresiko tertular HIV/AIDS

Setelah melakukan wawancara dengan Guru BK sebagian besar siswa belum pernah melakukan perilaku yang beresiko tertular HIV/AIDS

Penelitian ini dilakukan di 4 sekolah diantaranya 2 sekolah negeri, 2 sekolah swasta ini untuk membandingkan karena pengamatan peneliti grade 4 sekolah ini hampir sama sehingga itu salah alasan kenapa 4 sekolah dijadikan sample, selain itu letak 4 sekolah tersebut sudah bisa mewakili tiap kecamatan yang ada di
Kota Pekalongan, ditambah lagi letak 4 sekolah itu juga lokasi mudah dijangkau sehingga memudahkan peneliti. Letak 4 sekolah itu juga di kota sehingga akses untuk main ke tempat hiburan juga mudah, itulah menjadi alasan pemilihan lokasi penelitian.

Jumlah sample, kami peneliti mengambil kelas XI alasan dikarenakan kelas XI adalah usia yang sangat rawan godaan terhadap pergaulan bebas, narkoba yang ujungnya nanti penyakit HIV/AIDS. Jumlah sampel diharapkan dapat mewakili populasi yaitu sama dengan karakter sekolah secara acak. Dalam penelitian ini digunakan tingkat kesalahan 5 persen, agar peluang kesalahan semakin kecil. Adapun persebaran jumlah responden masingmasing Sekolah dapat dilihat pada :

Tabel 1 di bawah ini:

\begin{tabular}{|l|l|l|}
\hline No & Nama Sekolah & Jumlah Siswa \\
\hline 1 & MAN 2 Kota Pekalongan & 28 \\
\hline 2 & SMK Gatra Praja & 36 \\
\hline 3 & SMA Hasyim As'ari & 30 \\
\hline 4 & SMA N 4 Kota Pekalongan & 32 \\
\hline
\end{tabular}




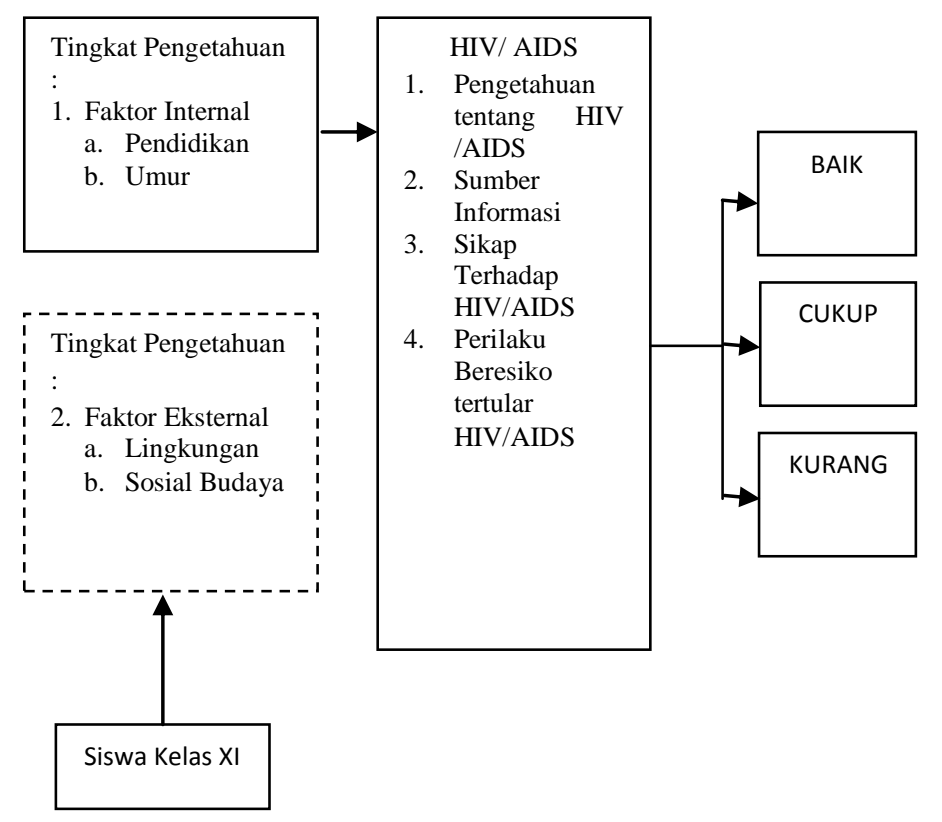

keterangan :

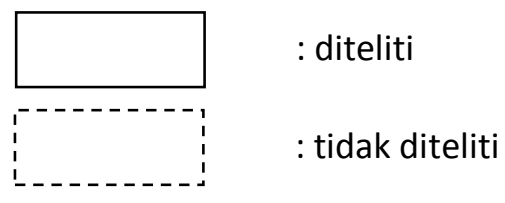

Data penelitian ini adalah data primer dan data sekunder. Instrumen penelitian dalam penelitian ini adalah kuesioner, kamera dan alat tulis untuk dokumentasi. Pengumpulan data primer dilakukan dengan memberikan kuesioner kepada siswa kelas XI di SMA/SMK/MA di Kota Pekalongan yang telah dipilih yang berisi tentang :

1. Pengetahuan Tentang HIV AIDS

2. Sumber Informasi tentang HIV AIDS

3. Sikap terhadap HIV AIDS

4. Perilaku yang beresiko tertular HIV AIDS.

dan selanjutnya data penelitian yang diperoleh akan diolah menggunakan analisis univariat pada masing masing variabel.

Kerangka konsep penelitian adalah suatu uraian dan dan visualisasi hubungan atau kaitan antara konsep satu terhadap konsep lainnya, atau antara variabel satu dengan variabel yang lain dari masalah yang akan dieteliti (Notoatmodjo, 2010). Kerangka konsep menyajikan konsep atau teori dalam bentuk kerangka konsep penelitian. Berdasarkan judul penelitian mengenai tingkat pengetahuan remaja tentang HIV/AIDS di Kota Pekalongan maka kerangka konsep penelitiannya adalah sebagai berikut

\section{Definisi Operasional}

Sesuai permasalahan dan tujuan penelitian, maka sebagai pedoman awal pengumpulan informasi digunakan definisi operasional yang dikembangkan seperti uraian dibawah ini :

1. Pengetahuan tentang HIV/AIDS adalah segala sesuatu yang dialami, dilihat dan di dengar tentang HIV/AIDS dan di gali berdasarkan kemampuan menjawab pertanyaan tentang apa itu HIV/AIDS, bagaimana gejala-gejala dini penderita HIV/AIDS, bagaimana cara penularannya, dan bagaimana upaya pencegahannya. 
Penilaian terhadap pengetahuan remaja terhadap penyakit HIV/AIDS dilakukan dengan mengajukan 42 pertanyaan kepada responden dengan skoring 1 untuk setiap jawaban yang benar dan 0 untuk jawaban yang salah, tidak menjawab maupun tidak tahu. Untuk setiap pertanyaan yang benar 2 diberi skor 2 dan untuk pertanyaan yang benar 3 diberi skor 3, dengan total skor sebanyak 42 dari 42 pertanyaan. Menurut Arikunto (2006), dapat dikategorikan sebagai berikut :

a. Skor 32-42 dikategorikan Baik

b. Skor 24-31 dikategorikan Cukup

c. Skor $<23$ dikategorikan Kurang.

2. Sumber Informasi tentang HIV/AIDS adalah semua sumber yang menginformasikan remaja tentang HIV/AIDS di Kota Pekalongan meliputi Guru, Orang Tua, Tenaga Kesehatan, Teman, Koran, dan Majalah.

3. Sikap terhadap HIV/AIDS adalah respon atau keyakinan seorang remaja terhadap penyakit HIV/AIDS. Penilaian terhadap sikap remaja terhadap penyakit HIV/AIDS dilakukan dengan mengajukan 12 pertanyaan kepada responden dengan skoring 1 untuk setiap jawaban yang benar dan 0 untuk jawaban yang salah, tidak menjawab maupun tidak tahu, dengan total skor sebanyak 12 dari 12 pertanyaan tersebut.

4. Perilaku beresiko tertular HIV/AIDS adalah segala sesuatu yang dapat menyebabkan menularnya penyakit HIV/AIDS. Penilaian terhadap perilaku beresiko tertular HIV/AIDS dilakukan dengan mengajukan 5 Pertanyaan kepada responden.

Selanjutnya akan disajikan data-data hasil riset di lapangan yang diperoleh mengenai tingkat pengetahuan remaja tentang HIV/AIDS di Kota Pekalongan Tahun 2014 yang meliputi :

\section{Data Tingkat Pengetahuan Remaja Tentang HIV/AIDS}

Selanjutnya akan di sajikan rata-rata dari data tingkat pengetahuan remaja tentang HIV/AIDS di Kota Pekalongan tahun 2014 adalah :

\section{Rata-Rata Tingkat Pengetahuan Remaja Tentang HIV/AIDS Di Kota Pekalongan}

\begin{tabular}{|l|l|l|}
\hline No & \multicolumn{1}{|c|}{ Nama Sekolah } & $\begin{array}{c}\text { Rata-rata Tingkat Pengetahuan } \\
\text { Remaja Tentang HIV/AIDS }\end{array}$ \\
\hline 1 & MAN 2 Kota Pekalongan & 25,7 \\
\hline 2 & SMK Gatra Praja & 20,9 \\
\hline 3 & SMA Hasyim Asyari & 23,2 \\
\hline 4 & SMA N 4 Kota Pekalongan & 25,2 \\
\hline
\end{tabular}

\section{Data Sumber Informasi Remaja Tentang HIV/AIDS}

Selanjutnya akan disajikan data sumber informasi tentang HIV/AIDS di Kota
Pekalongan Tahun 2014 sebagai berikut: 


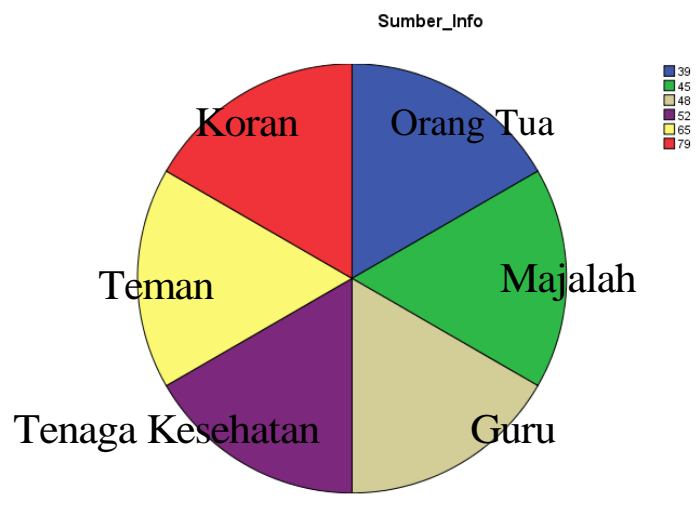

\section{Data tentang Sikap Remaja terhadap HIV/AIDS}

Kemudian akan diberikan data tentang sikap remaja terhadap HIV/AIDS di

Kota Pekalongan tentang HIV/AIDS adalah sebagai berikut :

\section{Data Tentang Sikap Remaja Tentang HIV/AIDS Di Kota Pekalongan Tahun 2014}

\begin{tabular}{|c|c|c|c|c|c|c|c|c|c|c|c|c|c|c|}
\hline \multirow{2}{*}{$\mathrm{NO}$} & \multirow{2}{*}{ Sekolah } & \multicolumn{13}{|c|}{ Nomor Soal } \\
\hline & & 1 & 2 & 3 & 4 & 5 & 6 & 7 & 8 & 9 & 10 & 11 & 12 & 13 \\
\hline 1 & $\begin{array}{l}\text { MAN 2 } \\
\text { Pekalongan }\end{array}$ & 2 & 3 & 4 & 2 & 2 & 2 & 3 & 2 & 2 & 2 & 3 & 2 & 2 \\
\hline 2 & $\begin{array}{l}\text { SMK Gatra } \\
\text { Praja }\end{array}$ & 3 & 3 & 4 & 3 & 2 & 2 & 3 & 1 & 2 & 3 & 4 & 1 & 2 \\
\hline 3 & $\begin{array}{l}\text { SMA Hasyim } \\
\text { Asyari }\end{array}$ & 2 & 3 & 3 & 2 & 1 & 1 & 3 & 1 & 2 & 2 & 3 & 1 & 1 \\
\hline 4 & $\begin{array}{l}\text { SMA N } 4 \\
\text { Pekalongan }\end{array}$ & 3 & 4 & 3 & 3 & 3 & 2 & 3 & 2 & 2 & 2 & 3 & 2 & 1 \\
\hline
\end{tabular}

4. Data tentang perilaku beresiko tertular HIV/AIDS

Berikut merupakan data tentang perilaku beresiko tertulah HIV/AIDS :

\section{Data Tingkat Perilaku Beresiko Tertular HIV/AIDS Di Kota Pekalongan Tahun 2014}

\begin{tabular}{|c|l|c|c|c|c|c|}
\hline \multirow{2}{*}{ NO } & \multicolumn{1}{|c|}{ Sekolah } & \multicolumn{5}{|c|}{ Nomor Soal } \\
\cline { 3 - 8 } & & 1 & 2 & 3 & 4 & 5 \\
\hline 1 & MAN 2 Pekalongan & 0 & 0 & 0 & 0 & 0 \\
\hline 2 & SMK Gatra Praja & 0 & 0 & 0 & 0 & 0 \\
\hline 3 & SMA Hasyim Asyari & 0 & 0 & 0 & 0 & 0 \\
\hline
\end{tabular}




\begin{tabular}{|l|l|l|l|l|l|l|}
4 & SMA N 4 Pekalongan & 1 & 1 & 0 & 0 & 0 \\
\hline
\end{tabular}

\section{HASIL DAN PEMBAHASAN}

Karakteristik responden dalam hal ini sangat penting. Responden pada penelitian ini adalah siswa SMA/SMK/MA di Kota Pekalongan dengan rata-rata usia antara 16-18 tahun. Responden pada penelitian ini diambil dari perwakilan sekolah pada tiap-tiap bagian Kota pekalongan yang meliputi Pekalongan Utara, Pekalongan Selatan, Pekalongan Barat, dan Pekalongan Timur. Pada penelitian ini akan diberikan salah satu karakteristik yaitu jenis kelamin. Selanjutnya akan diberikan tabel distribusi Responden berdasarkan Jenis Kelamin :

\begin{tabular}{|c|l|c|c|c|}
\hline No & \multicolumn{1}{|c|}{ Nama Sekolah } & Laki-laki & Perempuan & Jumlah \\
\hline 1 & MAN 2 Kota Pekalongan & 10 & 18 & 28 \\
\hline 2 & SMK GATRA PRAJA & 8 & 28 & 36 \\
\hline 3 & SMA HASYIM ASYARI & 6 & 24 & 30 \\
\hline 4 & SMA N 4 Kota Pekalongan & 8 & 24 & 32 \\
\hline
\end{tabular}

Selanjutnya akan diberikan penjelasan mengenai tingkat pengetahuan remaja tentang HIV/AIDS dikota Pekalongan pada tahun 2014.

\begin{tabular}{lcr} 
1. Tingkat Pengetahuan & \multicolumn{2}{r}{ Responden } \\
tentang HIV/AIDS & di $\begin{array}{r}\text { Kota } \\
\text { Pekalongan }\end{array}$
\end{tabular}

Pengetahuan responden tentang HIV/AIDS di Kota Pekalongan pada tahun 2014 dapat dilihat pada tabel frekuensi di bawah ini. Pada tabel dapat dilihat bagaimana jawaban dari setiap pertanyaan mengenai pengetahuan yang ditanyakan kepada responden.

\section{Rata-Rata Tingkat Pengetahuan Remaja Tentang HIV/AIDS (\%) Di Kota Pekalongan}

\begin{tabular}{|r|l|c|r|}
\hline No & \multicolumn{1}{|c|}{ Nama Sekolah } & $\begin{array}{c}\text { Rata-rata Tingkat } \\
\text { Pengetahuan Remaja } \\
\text { Tentang HIV/AIDS }\end{array}$ & Presentase \\
\hline 1 & MAN 2 Kota Pekalongan & 25,7 & $61,90 \%$ \\
\hline 2 & SMK Gatra Praja & 20,9 & $49,76 \%$ \\
\hline 3 & SMA Hasyim Asyari & 23,2 & $55,24 \%$ \\
\hline 4 & SMA N 4 Kota Pekalongan & 25,2 & $60 \%$ \\
\hline \multicolumn{2}{|c|}{ Rata-rata (\%) } \\
\hline
\end{tabular}

Berdasarkan tabel diatas maka diperoleh rata-rata tingkat pengetahuan remaja tentang HIV/AIDS adalah 56,73\% dengan kata lain bahwa tingkat pengetahuan remaja tentang HIV/AIDS di Kota Pekalongan adalah dengan kategoi cukup.

\section{Sumber Informasi Responden Megenai HIV/AIDS}


Berdasarkan diagram pie chart diatas paling banyak sumber informasi (informan) yang memberikan informasi mengenai HIV/AIDS di Kota Pekalongan adalah Guru yaitu sebesar $24,08 \%$ kemudian baru disusul dengan tenaga kesehatan dan majalah.

\section{Sikap Responden Tentang HIV/AIDS}

Akan diberikan tabel rata-rata tingkat pengetahuan remaja tentang HIV/AIDS di Kota Pekalongan Tahun 2014 sebagai berikut :

\section{Rata-Rata Data Tentang Sikap Remaja Tentang HIV/AIDS Di Kota Pekalongan Tahun 2014}

\begin{tabular}{|c|c|c|c|c|c|c|c|c|c|c|c|c|c|c|}
\hline \multirow{2}{*}{ NO } & \multirow{2}{*}{ Sekolah } & \multicolumn{13}{|c|}{ Nomor Soal } \\
\hline & & 1 & 2 & 3 & 4 & 5 & 6 & 7 & 8 & 9 & 10 & 11 & 12 & 13 \\
\hline 1 & $\begin{array}{ll}\text { MAN } & 2 \\
\text { Pekalongan } & \end{array}$ & 2 & 3 & 4 & 2 & 2 & 2 & 3 & 2 & 2 & 2 & 3 & 2 & 2 \\
\hline 2 & $\begin{array}{ll}\text { SMK } & \text { Gatra } \\
\text { Praja } & \end{array}$ & 3 & 3 & 4 & 3 & 2 & 2 & 3 & 1 & 2 & 3 & 4 & 1 & 2 \\
\hline 3 & $\begin{array}{ll}\text { SMA } & \text { Hasyim } \\
\text { Asyari } & \\
\end{array}$ & 2 & 3 & 3 & 2 & 1 & 1 & 3 & 1 & 2 & 2 & 3 & 1 & 1 \\
\hline 4 & $\begin{array}{lrl}\text { SMA N } & 4 \\
\text { Pekalongan } & \end{array}$ & 3 & 4 & 3 & 3 & 3 & 2 & 3 & 2 & 2 & 2 & 3 & 2 & 1 \\
\hline \multicolumn{2}{|c|}{ Rata-Rata } & 3 & 3 & 3 & 2 & 2 & 2 & 3 & 1 & 2 & 2 & 3 & 2 & 2 \\
\hline
\end{tabular}

Berdasarkan tabel diatas responden mempunyai menjawab setuju terhadap pertanyaan-pertanyaan mengungkapkan sikap terhadap HIV/AIDS yaitu pertanyaan 1,2,3,7,11. Ada juga responden menyatakan kurang setuju terhadap pertanyaan yang menyatakan sikap yakni pertanyaan 4,5,6,9,10,12, dan 13. Kemudian ada juga responden yang menyatakan sikap tidak setuju terhadap pertanyaan no 8 yakni penyakit HIV/AIDS adalah penyakit kutukan.

\section{Perilaku Beresiko tertular HIV/AIDS}

Akan diberikan tabel perilaku beresiko tertular HIV/AIDS di Kota Pekalongan Tahun 2014 sebagai berikut

\section{Tingkat Perilaku Beresiko Tertular HIV/AIDS Di Kota Pekalongan Tahun 2014}

\begin{tabular}{|c|l|c|c|c|c|c|}
\hline \multirow{2}{*}{ NO Sekolah } & \multicolumn{5}{|c|}{ Nomor Soal } \\
\cline { 3 - 8 } & & 1 & 2 & 3 & 4 & 5 \\
\hline 1 & MAN 2 Pekalongan & 0 & 0 & 0 & 0 & 0 \\
\hline 2 & SMK Gatra Praja & 0 & 0 & 0 & 0 & 0 \\
\hline 3 & SMA Hasyim Asyari & 0 & 0 & 0 & 0 & 0 \\
\hline 4 & SMA N 4 Pekalongan & 1 & 1 & 0 & 0 & 0 \\
\hline
\end{tabular}


Berdasarkan tabel perilaku beresiko tertular HIV/AIDS di Kota Pekalongan Tahun 2014 hampir semua responden tidak pernah melakukan perilaku beresiko tertular HIV/AIDS tetapi ada satu responden yang menjawab pernah berhubungan sex dengan teman dan pernah berhubungan sex dengan pacar.

\section{KESIMPULAN}

Selanjutnya akan diberikan kesimpulan, saran sebagai berikut :

\section{Kesimpulan Penelitian}

Tingkat pengetahuan remaja tentang HIV/ AIDS di Kota Pekalongan adalah cukup sebesar ( $56,73 \%)$

\section{Saran}

a. Saran terhadap stakeholder terkait dengan hasil penelitian

1. Stakeholder terkait dapat meningkatkan sosialisasi terhadap remaja tentang pengetahuan HIV / AIDS agar tingkat pengetahuan remaja menjadi naik

2. Adanya koordinasi antat instansi dalam memberikan sosialisasi kepada masyarakat

3. Memberikan sosialisasi kepada seluruh lapisan masyarakat agar info yang diberikan tersebar luas.
4. Menambah jenis media info yang digunakan untuk sosialisasi HIV/AID

b. Saran terhadap stakeholder terkait dengan pelaksanaan kegiatan riset tematik/riset unggulan Stakeholder membuat panduan pelaksanaan riset unggulan yang lebih baik dan jelas

c. Usulan penelitian lanjutan adalah Strategi Promosi Kesehatan Bagi Remaja Mengenai HIV/AIDS di Kota Pekalongan.

\section{DAFTAR PUSTAKA}

Moleong, Lexy J, 1995, Metdodologi Penelitian Kualitatif edisi revisi, Bandung : PT Remaja Rasdarkarya

Prasetyo, dkk, 2007, Family and Children Affected by HIV and Aids di Indonesia, Pusat Penelitian Kesehatan UI

Strategi Nasional Penanggulangan HIV dan AIDS 2007-2010, Jakarta : KPA 2007

Siregar, Fazidah A, 2004, Pengenalan dan Pencegahn AIDS, Fakutas Kesehatan Masyarkat Universitas Sumatera Utara. 